Матеріали Всеукраїнської науково-практичної конференчії «Актуальні питання діагностики, лікування, раціональної фармакотерапії, диспансеризації та реабілітації в практичі сімейного лікаря»

DOI

\title{
ХАРАКТЕРИСТИКА ПОРУШЕНЬ ЛІПІДНОГО ОБМІНУ У ПАЦІЄНТІВ 3 АРТЕРІАЛЬНОЮ ГІПЕРТЕНЗІЄЮ ТА МЕТАБОЛІЧНИМ СИНДРОМОМ
}

ФО. В. Ананьєва, Д. В. Казанжи

Одеський національний медичний університет

Актуальність. Пацієнти з артеріальною гіпертензією (АГ) та метаболічним синдромом (МС) належать до групи високого кардіоваскулярного ризику та потребують активної модифікації усіх факторів ризику, насамперед дисліпідемії.

Мета роботи. Вивчити структуру та типи порушень ліпідного обміну у пацієнтів з АГ та МС, наявність супутньої патології, прихильність до гіполіпідемічної терапії.

Матеріали і методи. Проведено комплексне клініко-лабораторно-інструментальне обстеження 76 амбулаторних пацієнтів з АГ ІІ-ІІІ стадії в поєднанні з МС (чоловіків - 32, жінок - 48), середній вік $(66 \pm 5,9)$ років.

Програма дослідження включала аналіз амбулаторних карток, вимірювання артеріального тиску, окружності талії, маси тіла з визначенням індексу маси тіла (IMT), ЕКГ, ліпідограму, дослідження глюкози, глікозильованого гемоглобіну, креатиніну, сечової кислоти, трансаміназ, ультразвукове дослідження органів черевної порожнини та нирок.

Діагноз МС був встановлений за критеріями Міжнародної асоціації діабету, 2005; діагноз гетерозиготної спадкової гіперхолестеринемії (ГХЕ) згідно з критеріями MedPed та ВОО3.

Результати дослідження. У всіх обстежених пацієнтів з АГ та МС були наявні абдомінальне ожиріння та порушення ліпідного обміну. Цукровий діабет (ЦД) 2 типу мали 31 (40,8\%), порушення толерантності до глюкози - 25 (32,9\%), загалом 56 (73,7\%) пацієнтів. Серед супутньої патології було виявлено: документована ішемічна хвороба серця (IXC) - у 63 (82,9\%), надлишкова вага тіла -у 32 (42,1\%), ожиріння - у 31 (40,8\%), неалкогольна хвороба печінки (НАЖХП) - у 44 (57,9 \%), хронічна хвороба нирок (XXН) - у 30 (39,5 \%), хронічний панкреатит - у 26 (34,2 \%), порушення пуринового обміну - у 21 (27,6 \%), гіпотиреоз - у 9 (11,84 \%) пацієнтів.
Згідно з класифікацією Фрідрексона, у 68 (89,47\%) пацієнтів виявлено гіперліпідемію II типу (Ilа тип - у 39 (51,3\%), ІІв тип - у 29 (38,15\%)), 3 V типом було 6 (7,89 \%), з IV типом - 2 (2,63\%) пацієнти.

Вторинна ГХЕ виявлена у $67(88,1 \%)$ пацієнтів. Причинами вторинної ГХЕ є цукровий діабет, гіпо-

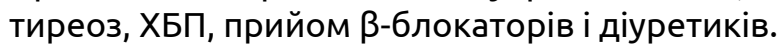

Достовірна гетерозиготна спадкова ГХЕ встановлена у 1 (1,3\%), можлива - у 8 (10,5 \%) пацієнтів.

Регулярно приймають 2 препарати 8 (10,5 \%), 3 препарати - 15 (19,7\%), 4 препарати - 28 (36,8 \%), 5 препаратів - 25 (32,9\%), тобто 3 та більше препаратів приймають 68 (89,5 \%) пацієнтів. 3 них

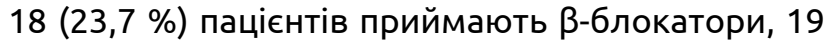
(25 \%) - тіазидні діуретики, які можуть погіршувати ліпідний та вуглеводний обміни.

Медикаментозну терапію дисліпідемії не проводили 30 (39,5\%), а припинили прийом статинів 46 (60,52 \%) пацієнтів. Основними причинами низького комплаєнсу є висока вартість препаратів, відсутність відчутного ефекту від прийому, поліпрагмазія, можливі побічні реакції.

\section{Висновки:}

1. У пацієнтів з АГ та МС виявлена численна коморбідна патологія, серед якої частіше зустрічаються IXC, ЦД 2 типу, НАЖХП, XXН, з приводу чого 89,5 \% пацієнтів постійно приймають 3 та більше препаратів.

2. Частіше зустрічається II тип гіперліпідемії за Фрідрексоном (68 $(89,47 \%))$, який $\epsilon$ високоатерогенним.

3. Первинна ГХЕ встановлена у $9(11,8 \%)$ пацієнтів (достовірна гетерозиготна спадкова ГХЕ - у $1(1,31 \%)$, можлива - у $8(10,5 \%))$. Вторинна ГХЕ виявлена у $67(88,1 \%)$ пацієнтів.

4. Основними причинами відмови від медикаментозного лікування $\epsilon$ фінансова, недостатня обізнаність та поліпрагмазія. 